\title{
MAKNA KONOTATIF GAYA BAHASA METAFORA DALAM KUMPULAN CERPEN SENYUM KARYAMIN KARYA AHMAD TOHARI
}

\author{
Desi Denni Uli Sitinjak ${ }^{1}$, Sumiharti \\ Program Studi Pendidikan Bahasa dan Sastra Indonesia, \\ Fakultas Keguruan dan Ilmu Pendidikan, Universitas Batanghari, \\ Jambi \\ Desidenni52@gmail.com \\ Harti.sumi@yahoo.com
}

\begin{abstract}
This research identifies literary work in the form of short story. The aim of this research is to describe connotative meaning of metaphor figurative language on Kumpulan Cerpen Senyum Karyamin Karya Ahmad Tohari. This research is qualitative descriptive with structural approach. The data of this research is sentences which contains metaphor figurative language on Kumpulan Cerpen Senyum Karyamin Karya Ahmad Tohari. The source of the data is Kumpulan Cerpen Senyum Karyamin by Ahmad Tohari. Based on the result of the analysis, it can be concluded that there are 43 expressions which is found on 13 titles of Kumpulan Cerpen Senyum Karyamin Karya Ahmad Tohari. Those expressions have connotative meaning such as "burung nakal" which means "burung yang menganggu", word "bisu" which means "tidak dapat berkata apa-apa", "semangatnya rontok" which means "tidak bersemangat". Based on those 13 titles analysis, it can be concluded that Senyum Karyamin is a short story which dominantly uses connotative metaphor of figurative language which implies someone's life with hard-work while Orang-orang Sebrang Kali implies that a human is like a chicken with its worse habit, and does not really use connotative metaphor of figurative language.
\end{abstract}

Keywords: Metaphor, Connotative Meaning, Short Story Collection

\footnotetext{
${ }^{1}$ Mahasiswa Program Studi Pendidikan Bahasa dan Sastra Indonesia, Fakultas Keguruan dan Ilmu Pendidikan, Universitas Batanghari, Jambi

${ }^{2}$ Dosen Program Studi Pendidikan Bahasa dan Sastra Indonesia, Fakultas Keguruan dan Ilmu

Pendidikan, Universitas Batanghari, Jambi

Makna Konotatif Gaya Bahasa Metafora dalam Kumpulan Cerpen Senyum Karyamin Karya

Ahmad Tohari 


\section{PENDAHULUAN}

Kemampuan manusia untuk berkomunikasi sebenarnya bukan hanya terletak pada kemampuan cara berpikirnya melainkan juga terletak pada kemampuan cara berbahasanya. Proses komunikasi dapat dilakukan manusia melalui bahasa. Oleh karena itu, tanpa bahasa, komunikasi tidak dapat dilakukan dengan baik dan interaksi sosial pun tidak pernah terjadi (Rahmawati dan Rahima, 2019:244). Rofii dan Hasibuan (2019) mengatakan "Fungsi bahasa yang paling mendasar ialah sebagai alat komunikasi. Bahasa digunakan masyarakat sebagai alat pergaulan antarsesama dan alat untuk menyampaikan sebuah pikiran". Maka dari itu bahasa sangat penting bagi manusia untuk berkomunikasi antar sesama manusia.

Bahasa digunakan juga dalam karya sastra, karena karya sastra tidak mungkin mewujudkan dirinya baik lisan maupun tertulis tanpa bahasa. Hubungan bahasa dan sastra dalam bahasa, digunakan untuk mengungkapkan daya imajinasi dan pengalaman pengarang. Karya sastra tidak disusun begitu saja tanpa pemakaian bahasa yang indah yang memberikan efek tertentu kepada pembacanya. Penggunaan gaya bahasa merupakan pemanfaatan kekayaan oleh seseorang dalam bertutur atau menulis, pemakaian ragam tertentu.

Pentingnya bahasa sebagai alat komunikasi dan gaya bahasa sebagai pelengkap dan warna dalam komunikasi, tidak sah apabila dalam karya sastra para pengarang tidak memberikan kesan imajinatif bagi pembaca dengan tidak memperhatikan wujud dari bahasa tersebut. Adanya gaya bahasa yang digunakan oleh pengarang dapat mengekspresikan pengalaman batin dan menampilkan kepribadiannya, sehingga karya sastra yang ditulis memiliki ciriciri yang personal.
Stilistika atau gaya bahasa seorang pengarang tentu berbeda dengan pengarang lainnya. Hal ini disebabkan gaya bahasa merupakan kepribadian seseorang pengarang dalam penyampaian melalui gaya bahasanya. Semakin baik gaya bahasa seseorang pengarang, maka semakin baik pula penilaian terhadap pengarang tersebut. Melalui gaya bahasa, pengarang dapat menuangkan nilai ke dalam karyanya sehingga dapat menggugah rasa keindahan berbahasa pada pembaca. Penggunaan gaya bahasa atau stilistika dalam karya sastra merupakan suatu ekspresi seorang pengarang dalam mengembangkan bahasa sebagai bahan untuk karyanya agar memiliki keindahan dan sarat akan makna yang harmonis. Gaya bahasa tersebut timbul karena pengarang menuangkan idenya. Apapun isi dari karya sastra jika dikaitkan dengan gaya bahasa akan semakin indah, sebaliknya jika penulis atau pengarang tidak mementingkan gaya bahasa bisa saja karyanya monoton bahkan dapat membuat bosan pembacanya.

Semantik adalah lambang-
lambang atau tanda-tanda yang menyatakan makna, hubungan makna dengan yang lain, semantik pencakup makna kata, perkembangannya dan perubahannya. Di sisi lain, kata semantik ini dapat digunakan dalam bidang linguistik dengan hal-hal yang ditandainya. Atau dengan kata lain semantik adalah bidang studi dalam linguistik yang mempelajari makna atau arti bahasa. Rofii (2017) mengatakan Semantic objects include the meaning of words as well as sentences. Objek kajian semantik mencakup makna kata serta kalimat. Oleh karena itu, kata semantik dapat diartikan sebagai ilmu tentang arti yaitu salah satu dari tiga tataran analisis bahasa: fonologi, gramatikal, dan semantik (Chaer, 2009:2). 


$\begin{array}{ccc}\text { Seorang } & \text { sastrawan } & \text { dalam } \\ \text { memperindah } & \text { karyanya } & \text { sering }\end{array}$
menggunakan gaya bahasa perbandingan. Gaya bahasa perbandingan dianggap dapat melukiskan, dan mengiaskan suatu cerita sehingga menjadi indah serta menarik untuk dibaca. Salah satu gaya bahasa perbandingan yang kerap digunakan oleh pengarang yakni metafora. Gaya bahasa metafora memiliki pengertian membandingkan sesuatu hal dengan hal yang lain tanpa mempergunakan kata-kata hubungan pembanding.

Salah satu karya sastra yang menggunakan gaya bahasa metafora adalah cerpen. Dengan adanya gaya bahasa metafora di dalam cerpen maka dapat membuat cerpen tersebut lebih bermakna saat dibaca, karena cerpen merupakan salah satu karya sastra yang tersusun dari bermacam unsur-unsur. salah satu unsunya gaya bahasa sebagai pengungkapan maksud pengarang dalam karyanya. Melalui gaya bahasa perbandingan metafora yang terdapat dalam cerpen membuat pemikiran pembaca tidak hanya menuju ke satu makna sehingga semakin tertarik dan tertantang pula pembaca untuk memaknainya. Banyak penggunaan gaya bahasa demi mencapai keestetikaan dan keanekaragaman bahasa dalam cerpen yang diciptakan oleh pengarang, khususnya pada bagian gaya bahasa metafora. Cerpen dituntun menyampaikan sesuatu serba ringkas dan tidak dibuat secara detail khusus yang bersifat memperpanjang cerita.

Hubungan bahasa dengan fungsi artistik terdapat dalam kajian stilistika. Hal tersebut menerangkan sesuatu dalam dunia kesastraan dan maknanya. Kajian gaya bahasa stilistika juga bertujuan untuk menentukan seberapa jauh dan dalam pengarang menggunakan tandatanda linguistik untuk memperoleh efek khusus. Hasilnya akan memperkaya pengetahuan, pemahaman, dan wawasan terhadap bahasa dan penggunaan bahasa dalam teks sastra.

Berbicara mengenai cerpen tidak dapat dilepaskan dari bahasa kias, perimajinasian, dan perlambangan atau gaya bahasa. Penggunaan gaya bahasa banyak digunakan oleh pengarang dalam menciptakan sebuah cerpen karena dapat menimbulkan kesan indah sekaligus banyak makna, seperti Kumpulan Cerpen Senyum Karyamin Karya Ahmad Tohari.

Ahmad Tohari merupakan salah satu sastrawan Indonesia yang banyak memberi sumbangsih melalui karyakaryanya yang banyak mengangkat permasalahan sosial. Ahmad Tohari tidak pernah melepaskan diri dari pengalaman hidup kedesaannya, salah satunya adalah Cerpen Senyum Karyamin Karya Ahmad Tohar. Cerpen ini mengangkat tentang unsur kedesaanya sebagai latar. Dengan mengangkat tema-tema sosial yang terkadang tidak pernah terpikirkan oleh mereka yang hidup dalam modernisasi.

Cerpen dibuat berdasarkan ide kreatif dan hasil imajinasi pengarangnya. Dalam menulis cerpen pengarang banyak berimajinasi dengan kehidupan yang nyata karena dengan adanya aliran imajinatif pembaca akan ikut larut dalam cerita yang disampaikan pengarang. Cerpen biasanya berisikan cerita hidup sang pengarang atau sebuah cerita yang menyangkut masalah kehidupan lain yang ditulis secara ringkas dan singkat. Indonesia merupakan contoh negara yang banyak menghasilkan cerpen.. Cerpencerpen tersebut diterbitkan dalam sebuah buku, media cetak (seperti : koran, majalah, dan buku-buku) dan internet. Dari sekian banyaknya cerpen yang diterbitkan di Indonesia salah satunya cerpen yang terkenal adalah Senyum Karyamin Karya Ahmad Tohari.

Menurut pengamatan peneliti anak muda zaman sekarang lebih suka dengan cerpen yang gaul dan sesuai 
dengan hasrat mereka terlebih mereka sangat menyukai cerpen yang cara penyampaian bahasa nya mengandung makna yang membuat imajinasi pembaca lebih bergama-ragam. Berdasarkan hal tersebut peneliti tertarik untuk mengkaji kumpulan cerpen yang penyampaian ceritanya disampikan menggunakan gaya bahasa metafora.

Adapun kumpulan cerpen yang akan peneliti kaji adalah cerpen Senyum Karyamin karya Ahmad Tohari yang memiliki makna kias yang disampaikan lewat gaya bahasa metafora. Sesuai dengan alasan peneliti maka judul skripsi ini adalah Analisis Makna Konotatif Dalam Gaya Bahasa Perbandingan Pada Kumpulan Cerpen Senyum Karyamin Karya Ahmad Tohari Penelitian ini difokuskan kepada makna konotatif dalam gaya bahasa metafora pada kumpulan Cerpen Senyum Karyamin Karya Ahmad Tohari

Berdasarkan dari fokus penelitian di atas maka pertanyaan penelitian ini adalah, bagaimana makna konotatif dalam gaya bahasa metafora pada kumpulan Cerpen Senyum Karyamin Karya Ahmad Tohari?

Sesuai dengan fokus dan pertanyaan penelitian yang telah diuraikan di atas, maka tujuan penelitian adalah untuk mendeskripsikan makna konotatif dalam gaya bahasa metafora yang terdapat pada Kumpulan Cerpen Senyum Karyamin Karya Ahmad Tohari.

Secara teoretis, hasil penelitian ini diharapkan dapat bermanfaat sebagai pengembangan dalam pembelajaran teori sastra khususnya analisis makna terhadap pemakaian metafora dan dapat memperkaya khasanah ilmu pengetahuan khusunya dalam ilmu bidang bahasa dan sastra.

Secara praktis, hasil penelitian ini diharapkan dapat bermanfaat untuk beberapa pihak, sebagai beirkut. a. Bagi pembaca, hasil penelitian ini diharapkan dapat menginformasikan penggunaan gaya bahasa metafora dalam kumpulan cerpen Senyum Karyamin karya Ahmad Tohari.

b. Bagi mahasiswa, dengan hasil hasil penelitian ini diharapkan dapat memahami dan menilai karya sasrta berdasarkan gaya bahasanya, khusunya penggunaan metafora dalam cerpen.

c. Bagi peneliti selanjutnya, hasil penelitian ini dapat digunakan sebagai bahan referensi bagi peneliti yang ingin meneliti topik penelitiannya relevan dengan penelitian ini.

\section{METODE PENELITIAN}

Dalam penelitian sastra terdapat beberapa sudut pandang atau pendekatan dalam menganalisis objeknya. Perbedaan sudut pandang ini kemudian memunculkan adanya berbagai jenis penelitian sastra. Oleh karena itu, jenis penelitian sastra tergantung dari sudut pandang mana yang dipakai peneliti dalam mengalisis objek kajiannya (Rahima, 2017:1).

Jenis penelitian ini adalah penelitian deskriptif. "Penelitian deksriptif adalah cara kerja penelitian yang dimaksudkan untuk mengambarkan, melukiskan, atau memaparkan keadaan suatu objek secara apa adanya, sesuai dengan situasi dan kondisi pada saat penelitian dilakukan (Ibrahim, 2015: 59)."

"Penelitisn kualitatif adalah jenis penelitian yang temuan-temuannya tidak diperoleh dari melalui prosedur kualifikasi, perhitungan statistik, atau bentuk cara-cara lainnya yang menggunakan ukuran dengan angka (Gunawan, 2013:82)." Penelitian kualitatif menjelaskan sesuatu yang berkaitan dengan nilai atau makna yang berkaitan dengan kata-kata tidak menggunakan prosedur statistik. 
penelitian ini menggunakan penelitian deskriptif kualitatif untuk mendeskripsikan makna gaya bahasa metafora dalam Cerpen Senyum Karyamin Karya Ahmad Tohari.

"Data adalah sumber informasi yang akan diseleksi sebagai bahan analisi (Siswantoro, 2010: 70)" Data yang relevan menjadi syarat utama dalam peneltian untuk dijasikan sebagai bahasa penelitian. Adapun data dalam penlitian ini yaitu berupa ujaran, kalimat atau proposisi yang mengandung gaya bahasa metafora dalam Cerpen Senyum Karyamin Karya Ahmad Tohari

Sumber data diperoleh berdasarkan objek yang akan diteliti. "Sumber data terkait dengan subjek penelitian dari mana data diperoleh" (Siswantoro, 2010:72) Sumber data dalam penelitian ini adalah Kumpulan Cerpen Senyum Karyamin Karya Ahmad Tohari

Dalam mengumpulkan data, digunakan memedomani langkah-langkah pengumpulan data yang diperkenalkan oleh Levi-Struss (dalam Rafiek, 2010:76). Teknik pengumpulan data dalam penelitian ini dilakukan dengan langkah-langkah sebagai berikut:

1. membaca dengan seksama Kumpulan Cerpen Senyum Karyamin Karya Ahmad Tohari;

2. menandai bagian kata-kata, kalimat, atau paragraf yang berhubungan dengan metafora hidup dan metafora mati serta makna konotatif dalam gaya bahasa metafora dalam Kumpulan Cerpen Senyum Karyamin Karya Ahmad Tohari;

3. mencatat aspek-aspek yang berkaitan dengan makna konotatif dalam gaya bahasa metafora dalam Kumpulan Cerpen Senyum Karyamin Karya Ahmad Tohari;

4. kemudian mengumpulkan data yang berhubungan dengan makna konotatif gaya bahasa perbandingan aspek metafora dalam Kumpulan Cerpen Senyum Karyamin Karya Ahmad Tohari.

"Analisis data merupakan suatu proses mengatur urutan data, mengkordinasikan ke dalam suatu pola, kategori, dan satuan uraian dasar (Patton dalam Muhammad 2011: 221)." Dalam penelitian ini analisis data dilakukan dengan model alur yang dikemukakan oleh Miles dan Hubberman. Langkahlangkah nya adalah sebagai berikut.

1. Data yang telah diberikan tanda sesuai dengan pokok permasalahan kemudian ditabulasi ke dalam tabel tabulasi data.

2. Selanjutnya penulis menginterpretasikan data sesuai dengan makna konotatif gaya bahasa metafora Cerpen Senyum Karyamin Karya Ahmad Tohari.

3. Penulis menganalisis data sesuai dengan makna konotatif dalam gaya bahasa metafora yang terdapat dalam Cerpen Senyum Karyamin Karya Ahmad Tohari.

4. Penulis melakukan keabsahan data dengan mengkonsultasikan kepada pembimbing 1 dan pembimbing 2 kemudian hasil penelitian dikaitkan dengan metode penelitian serta data di cocokan dengan teori menurut Tarigan (2013)

5. Setelah dilakukan pengabsahan data, selanjutnya mendeskripsikan makna konotatif dalam gaya bahasa metafora yang terdapat dalam Kumpulan Cerpen Senyum Karyamin Karya Ahmad Tohari.

\section{HASIL DAN PEMBAHASAN}

Hasil penelitian menunjukan bahwa terdapat 43 kutipan makna konotatif gaya bahasa metafora dari Kumpulan Cerpen Senyum Karyamin Karya Ahmad Tohari. Kumpulan cerpen tersebut terdiri dari 13 judul cerpen.

Cerpen Senyum Karyamin merupakan cerpen yang yang dominan 
menggunakan makna konotatif gaya bahasa metafora yang mengkiaskan tentang kehidupan seseorang yang selalu bekerja keras, sedangkan cerpen Orangorang Sebrang Kali merupakan cerpen yang sedikit menggunakan makna konotatif gaya bahasa metafora yang mengiaskan tentang seorang manusia yang digambarkan seperti seekor ayam. Kutipan-kutipan tersebut dijelaskan sebagai berikut.

\section{Makna Konotatif Gaya Bahasa Metafora dalam Cerpen Senyum Karyamin Karya Ahmad Tohari}

Kutipan 1

"Kali ini Karyamin merayap lebih hatihati. Meski dengan lutut yang sudah bergetar, jemari kaki dicengkramkannya ke tanah" (SK.2015:1)

Pada kutipan 1, kata merayap biasanya digunakan untuk menggambarkan sifat binatang, akan tetapi, merayap dalam kutipan ini mengacu kepada tokoh Karyamin yang berjalan mendaki dan menurun untuk mengantarkan sebuah batu ke tujuannya. Pada kutipan tersebut merayap dibandingkan dengan Karyamin yang berjalan menaiki dan menuruni bukit.

Kutipan 2

"Sudah, min pulanglah kukira hatimu tertinggal di rumah sehingga kamu loyo terus, kata Sarji yang diam-diam iri pada istri Karyamin yang muda dan gemuk" (SK.2015:2)

Pada data 2 terdapat ungkapan hatimu tertinggal di rumah yang merupakan majas metafora karena bukan organ tubuh hati manusia yang dimaksudkan tertinggal, melainkan hatimu dalam bentuk kias. Hatimu berarti semangat tokoh tersebut. Metafora menjadi sarana untuk mengiaskan makna. Pembaca akan mengetahui maksud tersebut dengan melihat unsur yang digabungkan. Kajian sesuai dengan pendapat Tarigan (2013:15) yang mengatakan bahwa metafora merupakan pemakaian kata-kata yang bukan sebenarnya melainkan sebagai lukisan.

2. Kutipan Makna Konotatif Gaya Bahasa Metafora dalam Cerpen Jasa-jasa Buat Sanwirya Karya Ahmad Tohari

Kutipan 3

"Akan kita buktikan siapa di antara kita yang tidak kehilangan separo akal sehat" (JJBS.2015:9)

Pada data 3, terdapat ungkapan separo akal sehat yang merupakan gaya bahasa metafora karena kutipan separo akal sehat dalam kutipan ini bukan lah makna yang sebenarnya melainkan dilukiskan untuk seseorang yang akal pikirannya tidak semuanya berjalan tetapi hanya sebagian akal pikiran tersebut berjalan, kutipan tersebut biasa digunakan untuk mereka yang memiliki gangguan mental. Kajian tersebut sesuai dengan pendapat Tarigan (2013:15) yang mengatakan bahwa metafora merupakan pemakaian kata-kata yang bukan sebenarnya melainkan sebagai lukisan.

\section{Makna Konotatif Gaya Bahasa Metafora dalam Cerpen Si Minem Beranak Bayi Karya Ahmad Tohari}

Kutipan 4

"Apabila hal terakhir ini yang akan terjadi. Kasdu akan menjadi debu" (SMBB.2015:14)

Pada kutipan 4, terdapat ungkapan menjadi debu yang merupakan gaya bahasa metafora karena debu dalam kutipan ini bukan makna sebenarnya tetapi memiliki arti debu kotoran melainkan debu yang dilukiskan menjadi ciut atuapun menjadi takut. Kajian tersebut sesuai dengan pendapat Tarigan (2013:15) yang mengatakan bahwa metafora merupakan pemakaian kata-kata 
yang bukan sebenarnya melainkan sebagai lukisan.

Kutipan 5

"Berbeda jauh dengan penampilannya di hari-hari biasa yang begitu segar dan hidup. Anaknya hanya bergerak-gerak lemah seperti ulat yang kena sengat tabuan" (SMBB.2015:14)

Pada data 5 terdapat ungkapan seperti ulat yang kena sengat tabuan merupakan gaya bahasa metafora karena tidak mengandung makna sebenarnya yaitu seekor ulat yang terkena sengat lebah melainkan dilukiskan seperti seorang bayi yang dilahirkan belum genap 7 bulan sehingga hanya bisa bergerak sedikit demi sedikit seperti ulat yang terkena sengatan tawon. Karena ulat yang terkena sengatan tawon tidak dapat bergerak lagi. Kajian tersebut sesuai dengan pendapat Tarigan (2013:15) yang mengatakan bahwa metafora merupakan pemakaian kata-kata yang bukan sebenarnya melainkan sebagai lukisan.

\section{Makna Konotatif Gaya Bahasa Metafora dalam Cerpen Surabanglus Karya Ahmad Tohari}

Kutipan 6

"Kini aku sudah yakin betul kan singkong yang kita bakar itu. Jangan gila. Munyuk dan monyet pun tak mau memakannya.

Hanya perut celeng yang mampu bertahan terhadap racun singkong itu, singkong surabanglus" (S.2015:18)

Kutipan 6 terdapat ungkapan hanya perut celeng yang merupakan gaya bahasa metafora karena tidak mengandung makna sebenarnya, tetapi memiliki arti perut seekor binatang yang mampu memakan segalanya tapi dalam kutipan ini dikiaskan bahwa hanya perut binatang yang mampu memakan racun singkong tersebut. Perut celeng mempunyai arti kiasan perut yang mampu menampung segala makanan. dalam kutipan ini perut celeng dibandingkan dengan seseorang yang mampu memakan segalanya termasuk mampu memakan racun. Kajian sesuai tersebut dengan pendapat Purwandari (2012:203) yang mengatakan bahwa metafora merupakan gaya bahasa perbandingan yang membandingkan dua hal yang berbeda berdasarkan persamaannya.

\section{Makna Konotatif Gaya Bahasa Metafora dalam Cerpen Jasa-jasa Buat Sanwirya Karya Ahmad Tohari}

Kutipan 7

"Musgepuk bersungut-sungut. Danuringuring. Semangatnya rontok. Aku, meskipun belum lama disunat, bisa mengerti perasaanya" (TMBK.2015:23)

Pada data 6 Semangat nya rontok merupakan gaya bahasa metafora karena tidak mengandung makna sebenarnya yaitu semangat yang rontok melainkan dalam kutipan ini menggambarkan seseorang yang sedang putus asa karena tidak dapat membantu teman nya yang sedang terbaring lemah di kasur sehingga membuat nya tidak bersemangat lagi untuk membantu teman nya. Kata rontok biasa di gabungkan dengan rambut yang menjelaskan bahwa rambut seseorang sedang rontok atau gugur tetapi dalam kalimat pada data 6 kata rontok dipakai untuk menjelaskan seseorang yang telah putus asa. Kajian sesuai dengan teori Tarigan (2013:15) yang mengatakan bahwa metafora merupakan gaya bahasa yang di dalamnya terlihat dua gagasan: yang satu adalah suatu kenyataan, sesuatu yang dipikirkan, yang menjadi objek; dan yang satu lagi merupakan pembanding terhadap kenyataan tadi. Pada kutipan 7 terdapat ungkapan memukul-mukul bumi yang merupakan gaya bahasa metafora karena tidak mengandung 
makna sebenarnya yaitu kerbau yang memukul-mukul bumi melainkan dalam kutipan ini digambarkan seekor kerbau yang sedang menahan sakit saat diobatkan tetapi dia tidak tertahan dengan sakit itu sehingga iya mengibaskan ekornya ke tanah, bumi dalam kutipan tersebut bukan berarti isi bumi melainkan tanah yang ada di bumi, arti bumi dalam kutipan ini dilukiskan menjadi tanah. Kajian seoerti ini sesuai dengan teori Tarigan (2013:15) yang mengatakan bahwa metafora merupakan pemakaian kata-kata yang bukan sebenarnya melainkan sebagai lukisan.

\section{Makna Konotatif Gaya Bahasa Metafora dalam Cerpen Ah, Jakarta Karya Ahmad Tohari}

Kutipan 8

"Nah, awas kamu. Aku tidak ingin ada bangkai manusia yang pernah menginap di rumah ini. Kau tahu orangorang macam dia yang kini mayatnya tercampak di mana-mana" (AJ.2015:30)

Pada kutipan 8 terdapat ungkapan bangkai manusia yang merupakan gaya bahasa metafora karena tidak mengandung makna sebenarnya yaitu bangkai manusia atau mayat manusia melainkan memiliki arti seseorang penjahat yang menginap dirumah teman nya, sehingga istri nya tidak ingin seseorang tersebut ada di rumah nya, kata bangkai dalam kutipan tersebut dibandingkan dengan sesuatu yang bau dan busuk dan tidak berguna maka dari itu Galih dibandingkan dengan bangkai karena memiliki arti yang sama. Kajian seperti ini sesuai dengan pendapat Purwandari (2012:203) yang mengatakan bahwa metafora merupakan gaya bahasa perbandingan yang membandingkan dua hal yang berbeda berdasarkan persamaannya.

\section{Makna Konotatif Gaya Bahasa Metafora dalam Cerpen Blokeng Karya Ahmad Tohari}

\begin{abstract}
Kutipan 9
"Selebihnya, siapa pun tak sudi diperbandingkan apalagi dimiripkan dengan Blokeng. Ini kepongahan kampungku yang dengan gemilang telah berhasil memlihara rasa congkak dengan cara memanipulasi nilai martabat manusia" (B.2015:33)

Pada kutipan 9 terdapat ungkapan memanipulasi nilai martabat manusia yang merupakan gaya bahasa metafora karena kutipan tersebut mengartikan seseorang yang memainkan harga diri seseorang wanita tanpa mau bertanggung jawab, kata memanipulasi dalam kutipan tersebut dilukiskan sebagai mempermainkan nilai martabat seseorang. Kajian seperti ini sesuai dengan pendapat Tarigan (2013:15) yang mengatakan metafora merupakan pemakaian kata-kata yang bukan sebenarnya melainkan sebagai lukisan.
\end{abstract}

Kutipan 10

"Perih, tak peduli bayi itu sudah lama diidamkan, lagi pula anak seorang suami yang sah. Bagaimana tentang si Blokeng yang melahirkan anak antah berantah" (B.2015:34)

$$
\text { Pada kutipan } 10 \text { terdapat }
$$
ungkapan anak antah berantah yang merupakan gaya bahasa metafora karena memiliki arti seorang wanita yang melahirkan seorang bayi yang tidak diketahui siapa ayah dari bayi tersebut. Kata antah berantah dalam kutipan tersebut dilukiskan menjadi seorang anak yang tidak diketahui asal-usulnya. Karena kata antah berantah biasa terdapat di dalam cerita dunia khayal atau dongeng yang mengartikan ketidaktahuan. Kajian seperti ini sesuai dengan teori Tarigan (2013:15) yang mengatakan metafora merupakan 
pemakaian kata-kata yang bukan sebenarnya melainkan sebagai lukisan.

\section{Makna Konotatif Gaya Bahasa Metafora dalam Cerpen Syukuran Sutabawor Karya Ahmad Tohari}

Kutipan 11

"E, lha. Sabar Nak, sabar. Pertama, carilah kutu di kepalamu sendiri. Cari kesalahan pada dirimu mengapa jengkol ini tidak mau berbuah. Jangan tersega seperti itu” (SS.2015:39)

$$
\text { Pada kutipan } 11 \text { terdapat }
$$
ungkapan carilah kutu di kepalamu sendiri merupakan gaya bahasa metafora karena dalam kutipan ini mengartikan carilah kesalahan diri sendiri sebelum mencari kesalahan orang lain, kata kutu dalam konteks sebenarnya merupakan binatang kecil yang muncul akibat adanya bakteri, kutu sangat sulit ditemukan karena memiliki ukuran yang sangat kecil. tetapi dalam kutipan ini kata kutu dilukiskan menjadi kesalahan seseorang, karena mencari kesalahan orang lain sangatlah mudah tetapi mencari kesalahan sendiri sangat sulit dilakukan. Kajian seperti ini sesuai dengan pendapat Tarigan (2013:15) yang mengatakan metafora merupakan pemakaian kata-kata yang bukan sebenarnya melainkan sebagai lukisan.

\section{Kutipan-Kutipan Makna Konotatif Gaya Bahasa Metafora dalam Rumah yang Terang Karya Ahmad Tohari}

Kutipan 12

"Listrik sudah empat tahun masuk kampungku dan sudah banyak yang dilakukannya. Kampung seperti Mendapat injeksi tenaga baru yang membuatnya menggeliat penuh gairah" (RYT.2015:42)

$$
\text { Pada kutipan } 12 \text { terdapat }
$$
ungkapan injeksi tenaga baru yang merupakan gaya bahasa metafora karena dalam kutipan ini diartikan mendapatkan semangat baru ketika listrik telah hadir di kampungnya. Kata injeksi tenaga dalam kutipan ini bukan mengartikan mesin yang mengasilkan tenaga listrik tetapi melukiskan sebagai kekuatan baru yang membuat mereka-mereka yang tinggal di kampung lebih bersemangat lagi ketika listrik telah sampai ke desa mereka. Kajian seperti ini sesuai dengan pemdapat Tarigan (2013:15) yang mengatakan metafora merupakan pemakaian kata-kata yang bukan sebenarnya melainkan sebagai lukisan.

kutipan 13

"Ketika belum tahu latar belakang sikap ayah, aku sering membujuk. Loh, Mengapa aku dan ayah tidak ikut beramai-ramai bersama orang sekampung membunuh bulan" (RYT.2015:44)

Pada kutipan 12 terdapat ungkapan membunuh bulan yang merupakan gaya bahasa metafora karena membunuh bulan dalam kutipan tersebut memilik arti tidak lagi terlalu memerlukan cahaya dari bulan akibat adanya listrik di kampung tersebut, sehingga cahaya lebih mudah didapatkan. Kata membunuh bulan dibandingkan dengan ingin mematikan bulan, yang berarti ingin mematikan sesuatu. Dalam kutipan terusebut diceritakan warga ingin mematikan bulan karena bagi mereka cahaya dari listrik sudah sangat cukup. Hal seperti ini sesuai dengan pendapat Purwandari (2012:203) metafora merupakan gaya bahasa perbandingan yang membandingkan dua hal yang berbeda berdasarkan persamaannya.

\section{Makna Konotatif Gaya Bahasa Metafora dalam Cerpen Kenthus Karya Ahmad Tohari}

Kutipan 14

Makna Konotatif Gaya Bahasa Metafora dalam Kumpulan Cerpen Senyum Karyamin Karya 
"Kenthus telah dilambungkan dari kelas terbawah ke atas panggung kehidupan“(K.2015:47)

$$
\text { Pada kutipan } 14 \text { terdapat }
$$
ungkapan panggung kehidupan yang merupakan gaya bahasa metafora karena dalam kutipan ini panggung kehidupan diartikan sebagai strata kehidupan seseorang yang awalnya berkehidupan serba tidak cukup dapat kemudian merasakan berkehidupan mewah. Kata panggung sebenarnya memiliki arti bangunan atau lantai tinggi tetapi panggung kehidupan dalam kutipan ini dilukiskan menjadi jalan kehidupan seseorang yang telah merasakan naik turunnya kehiudupan dari strata rendah hingga akhirnya merasakan strata tinggi. Kajian seperti ini sesuai dengan pendapat Tarigan (2013:15) yang mengatakan metafora merupakan pemakaian kata-kata yang bukan sebenarnya melainkan sebagai lukisan.

\section{Makna Konotatif Gaya Bahasa Metafora dalam Cerpen Orang- orang Sebrang Kali Karya Ahmad Tohari}

Kutipan 15

"Tapi ya itu, Mas. Madrakum awet benar. Heran, nyawanya demikian betah dalam tubuh Madrakum yang melarat" (OOSK.2015:45)

Pada kutipan 15 terdapat ungkapan nyawanya demikian betah dalam tubuh yang merupakan kalimat yang mengandung makna konotatif karena kutipan tersebut menggambarkan seseorang yang sudah sekarat akibat penyakit yang di deritanya tetapi masih memiliki harapan hidup. Kata betah dalam kutipan ini melukiskan nyaman di satu tempat atau tetap ingin tinggal, sehingga digambarkan nyawanya tetap ada walaupun hidupnya sudah sangat sekarat akibat penyakit tersebut. Kajian seperti ini sesuai dengan pendapat
Tarigan (2013:15) yang mengatakan metafora merupakan pemakaian kata-kata yang bukan sebenarnya melainkan sebagai lukisan.

\section{Makna Konotatif Gaya Bahasa Metafora dalam Cerpen Wagon Jatilawang Karya Ahmad Tohari}

Kutipan 17

"Aku merasa tak bisa berbuat yang lain kecuali menyilahkan Sulam masuk, meski aku melihat tamuku agak masam wajahnya, Sulam kuajak menikmati kenduri” (WJ.2015:58)

Pada kutipan 17 terdapat ungkapan masam wajahnya yang merupakan gaya bahasa metafora karena memiliki arti memasang wajah yang tidak enak atau wajah cemberut. Kata masam biasa dipakai untuk mengecap rasa makanan tetapi dalam kutipan ini masam wajahnya diartikan memasang wajah yang tidak enak. Kajian tersebut sesuai dengan teori Tarigan (2013:15) yang mengatakan metafora merupakan pemakaian kata-kata yang bukan sebenarnya melainkan sebagai lukisan.

\section{Makna Konotatif Gaya Bahasa Metafora dalam Cerpen Pengemis dan Shalawat Badar Karya Ahmad Tohari}

Kutipan 18

"Bahkan beberapa di antara mereka sudah membajingloncat ketika bus masih berada di mulut terminal" (PDSB.2015:63)

Pada kutipan 18 terdapat ungkapan membanjingloncat yang merupakan gaya bahasa metafora karena mengartikan seseroang yang dengan cepat masuk ke dalam bus. Kata membanjingloncat dalam kutipan tersebut dilukiskan meloncat dengan cepat. Mulut terminal juga merupakan gaya bahasa metafora karena mulut terminal bukan lah arti yang

Makna Konotatif Gaya Bahasa Metafora dalam Kumpulan Cerpen Senyum Karyamin Karya 
sebenarnya melainkan bus yang berhenti di bagian pintu masuk terminal, mulut dilukiskan menjadi pintu masuk yang terletak di depan terminal. Kajian seperti ini sesuai dengan peendapat Tarigan (2013:15) yang mengatakan metafora merupakan pemakaian kata-kata yang bukan sebenarnya melainkan sebagai lukisan.

Kutipan 19

"Mereka terus bertengkar melalui katakata yang tidak sedap didengar" (PDSB.2015:65)

Pada kutipan terdapat ungkapan katakata yang tidak sedap merupakan gaya bahasa metafora karena memiliki arti perkataan yang tidak sopan dan tidak enak saat didengar. Kata tidak sedap umumnya memiliki arti tidak enak tetapi dalam kutipan ini kata tidak sedap dilukiskan menjadi tidak enak saat didengar. Kajian tersebut sesuai dengan pendapat Tarigan (2013:15) yang mengatakan metafora merupakan pemakaian kata-kata yang bukan sebenarnya melainkan sebagai lukisan.

\section{SIMPULAN}

Berdasarkan hasil analisis terhadap Kumpulan Cerpen Senyum Karyamin karya Ahmad Tohari, dapat disimpulkan bahwa terdapat 43 jumlah gaya bahasa metafora. Gaya bahasa tersebut terdapat dalam judul cerpen Senyum Karyamin, Jasa-Jasa Buat Sanwirya, Si Minem Beranak Bayi, Surabanglus, Tinggal Matanya BerkedipKedip, Ah, Jakarta, Blokeng, Syukuran Sutabawor, Rumah yang Terang, Kenthus, Orang-Orang Sebrang Kali, Wagon Jatilawang, Pengemis dan Shalawat Badar.

Cerpen Senyum Karyamin merupakan cerpen yang paling dominan mengandung makna konotatif yang disampaikan melalui gaya bahasa metafora karena dalam cerpen tersebut terdapat sembilan kutipan gaya bahasa metafora. Sementara Cerpen OrangOrang Sebrang Kali merupakan cerpen yang sedikit mengandung makna konotatif gaya bahasa metafora yaitu hanya satu kutipan.

Penggunaan gaya bahasa metafora dalam kumpulan 13 Cerpen Senyum Karyamin karya Ahmad Tohari, memunculkan ketaksaan sehingga akan muncul berbagai pemahaman sesuai dengan interpetasi masing-masing pembaca, melibatkan berbagai pilihan kata yang disediakan dan menjadi modus untuk berpikir dengan menyatakan suatu peristiwa lain. Gaya bahasa metafora dapat memberikan pengestetikaan atau memperindah gambaran peristiwa yang lebih hidup sehingga tidak membosankan bagi pembacan.

\section{Saran}

Adapun saran yang dapat disampaikan terkait dengan hasil penelitian ini, sebagai berikut. Disarankan guru bahasa Indonesia dapat menggunakan cerpen terhadap pelajaran gaya bahasa, agar siswa dapat lebih tertarik dan lebih berminat dalm proses belajarnya.

1. Disarankan kepada sastrawan agar terus menciptakan karya-karya yang memiliki makna positif sehingga generasi bangsa dapat termotivasi dengan karya sastra yang bermakna positif.

2. Disarankan kepada pembaca bahwa makna konotatif gaya bahasa metafora yang terdapat dalam Cerpen Senyum Karyamin karya Ahmad Tohari diterapkan dalam kehidupan bermasyarakat.

3. Disarankan kepada peneliti lain bahwa penelitian ini dapat dijadikan acuan bagi peneliti berikutnya yang akan mengkaji objek penelitian yang sama maupun objek yang berbeda. 


\section{DAFTAR PUSTAKA}

Chaer, Abdul. (2009). Semantik 1: Makna Leksikal Dan Gramatikal. Bandung: PT Refika Aditama.

Gunawan, Imam. (2013). Metode Penelitian Kualitatif. Jakarta:

Ibrahim. (2015). Metode Penelitian Kualitatif. Bandung: Alfabeta.

Muhammad. (2011). Memahami Riset Prilaku dan Sosial. Bandung: Pustaka Cendikia Utama.

Purwandari, Retno. (2012). Buku Pintar Bahasa Indonesia. Yogyakarta: Istana Media.

Rafiek, M. (2010). Teori Sastra: Kajian Teori dan Praktik. Bandung: Rafika.

Rahima, A. (2017). Literature Reception (a Conceptual Overview). Jurnal Ilmiah Dikdaya, 6(1), 1-16.

Rahmawati, S., \& Rahima, A. (2020). Makna Kontekstual dalam Lagu Luka Gilo pada Masyarakat Kabupaten Tebo Provinsi Jambi (Struktura-Hermeneutik). Aksara: Jurnal Ilmiah Pendidikan Bahasa dan Sastra Indonesia, 3(2), 243254.

Rofii, Afif. (2017). Model of ContextualBased Semantics Learning Materials (Research and Development at Indonesian Language and Literature Education Department, Faculty of Teachers Training and Education Batanghari University Jambi). Proceedings of the Sixth International Conference on Languages and Arts (ICLA 2017). Padang. https://www.atlantispress.com/proceedings/icla$\underline{17 / 25888900}$
Rofii, Afif. dan Hasibuan, Rizka Rani (2019) Interferensi Bahasa Batak Mandailing dalam Tuturan Berbahasa Indonesia Pada Acara Parpunguan Masyarakat Mandailing Kota Jambi. Aksara: Jurnal Ilmiah Pendidikan Bahasa dan Sastra Indonesia Vol. 3 No. $1 \quad$ April 2019 aksara.unbari.ac.id/index.php/aks ara/article/download/94/50

Siswantoro. (2010). Metode Penelitian Sastra. Yoyakarta: Pustaka Pelajar.

Tarigan, Henry Guntur. (2013). Pengajaran Gaya Bahasa. Bandung: Angkasa Bandung.

Tohari, Ahmad. (2013). Senyum Karyamin. Jakarta: PT Gramedia Jakarta. 